\title{
Effect of Protein and Calcium Microparticle feeding with Lactobacillus acidophilus or Citric Acid on Meat Quality
}

\author{
Rachel Rama Gradhinta ${ }^{1}$, Bambang Sukamto ${ }^{2}$ and Istna Mangisah ${ }^{2}$ \\ ${ }^{1}$ Student of Animal Husbandry and Agriculture, Diponegoro University \\ ${ }^{2}$ Teacher of of Animal Husbandry and Agriculture, Diponegoro University \\ Jl. Prof. H. Soedarto, S.H. Tembalang, Semarang, Indonesia \\ Corresponding author : Rachel Rama Gradhinta \\ Email : rarache198@gmail.com
}

\begin{abstract}
This research aims to determine the effect of administering a combination feed of calcium microparticle protein with Lactobacillus acidophilus or citric acid on fat digestibility and the meat of broiler chicken. The cattle used in this research are 15 days old broiler chickens, amounted in 160 chickens. The study uses complete random design (RAL) with 5 treatments and 4 repeat treatmens ( 8 chickens each). The treatment applied were as follows: T0 (non-microbial feed (protein 21\%)), T1 (non-microparticle feed $(18 \%$ protein + Lactobacillus acidophilus $1.2 \mathrm{ml}(108 \mathrm{CFU} / \mathrm{ml}))$, T2 (nonmicroparticle feed $(18 \%$ protein + Citric acid 1.2\%), T3 (Microparticle feed $(18 \%)+$ Lactobacillus acidophilus $1.2 \mathrm{ml}(108 \mathrm{CFU} / \mathrm{ml}))$, T4 (microparticle feed (18\% protein + Citric acid 1.2\%). The observed parameters are the digestibility of fat, fat mass of meat, the percentage of abdominal fat and the increase in body weight. The analyzed data results were variegated and continued using Duncan's multiple range test at a $5 \%$ probability. Treatment was given from the age of 15 days to 42 days. The results of the study show that the digestibility of fats that had the treatment of feeding protein and calcium microparticles with the addition of real effect Lactobacillus acidophilus is lower than the T0 and T2 but not unlike the T1 and T4 $(\mathrm{P}<0.05)$. The fat mass of meat and abdominal fats in the $\mathrm{T} 4$ treatment has a real difference $(\mathrm{P}<0.05)$ and at the lowest of the T0, T1 and T2 but different from T3. Higher weight increase in T3 treatment is compared to T1, T2 and T4 but not different from T0. Based on the results of the study it can be concluded that feeding microparticles of protein and calcium with Lactobacillus acidophilus $1.2 \mathrm{ml}$ can decrease fat digestibility and increase weight gain but not in the fat mass of meat and abdominal fat percentage.
\end{abstract}

Keywords : broiler, citric acid, Lactobacillus acidophilus, microparticle.

\section{Introduction}

A broiler is any chicken (Gallus gallus domesticus) that is bred and raised specifically for meat production to fulfill the omnivorous needs of animal proteins. Increased consumption of broiler chicken meat can be seen from statistical data indicating the consumption of proteins especially chicken meat in the year 2017 reaches $5.683 \mathrm{~kg} / \mathrm{capita} /$ year (Directorate General of Livestock and Animal Health Service, 2018). Consumption of high broiler chicken meat needs to be supported the high productivity of broiler chickens. Increased productivity can be seen from the quantity and quality of meat according to expectation of the people of low fat broiler chicken 
meat. Increased quality and quantity of broiler chickens production can be done by means of feeding microparticles as well as the addition of probiotics and acidifier.

The processing of feed material source of protein and calcium into microparticles aims to change the particle size of the feed to be smaller so that the digestive enzymes can work optimally in order to improve digestion as well as absorption. Broiler chicken rations with a particle size of 700-900 $\mu \mathrm{m}$ affect body weight and improve conversion (Addo et al., 2012).

The addition of Lactobacillus Acidophilus is expected to stimulate the digestive tract and increase healthy microbes are well developed can increase the amount of lactic acid bacteria that can produce the enzyme Bile Salt Hydrolase (BSH) ( Fajrina et al., 2014). BSH serves to deconjugate the bile salts so that the deconjugated bile salts are difficult to emulate fats and cause the blockage in digestibility of fat (Fadhilah et al., 2015).

The acidifier used is synthetic citric acid used to maintain microbial balance in the digestive tract of broiler chickens (Natsir and Sjofjan, 2008). Citric acid lowers the $\mathrm{pH}$ of the digestive tract to create an acidic atmosphere and affect the rate of digesta and reduce pathogenic bacteria that affect the digestibility (Yendy et al., 2014). Low pH causes lipase enzyme activity does not work optimally so that fat digestibility decreases (Kirana et al., 2017).

Based on the background above then a research is conducted on the use of feed as a source of protein and calcium microparticles coupled with Lactobacillus acidophilus or citric acid to the quality of meat and increase body weight broiler chickens. The benefit of this research is to find out about the influence on the digestibility of fat, the weight of abdominal fat and fat mass meat and the weight gain of broiler chickens.

The use of feed material sources of protein and calcium microparticles with the addition of Lactobacillus acidophilus or citric acid is expected to reduce the digestibility of fatty meats as well as the treatment of broiler chickens and increase body weight.

\section{Materials}

\section{Materials and Methods}

The research was conducted on November 17, 2018 - December 18, 2018 in a cage in Animal Feed and Nutrition Laboratory of Animal Husbandry and Agriculture Faculty, Diponegoro University Semarang.

The material used is 160 chickens of chicken broiler strains Cobb, Lactobacillus acidophilus (108 CFU/ml) with the isolate name of FNCC 0051 obtained from the Interuniversity Laboratories (PAU) Biotechnology University of Gadjah Mada and is in the laboratory of Livestock Physiology and biochemistry Faculty of Animal husbandry and Agriculture Diponegoro University, synthetic citric acid as acidifier, commercial ration of Charoen Pokphand 511, a treatment ration consisting of microparticles, fish flour microparticle, egg shells microparticle, milled corn, rice bran and premix, Virgin Coconut Oil (VCO), drinking water, disinfectant, ND-IB vaccine, $\mathrm{Fe}_{2} \mathrm{O}_{3}$ indicator, $\mathrm{HCl}$ $0.1 \mathrm{~N}$ and drugs. The tools used included flock cage, battery cage, incandescent lamps, feed spots, drinking water, ultrasound transducer, analytical scales and digital scales.

\section{Methods}

Preparation of research was done making soybean meal, fish meal and egg shell into microparticles. The manufacture of microparticles begins with grinding the 
feedstuffs then filtered and administered ultrasonic waves using the ultrasound transducer for 60 minutes. Feedstuffs that have been dissonified then dried with the help of sunlight. Cage preparation includes Cage sanitization, brooder making for DOC and preparing cage equipment.

Maintenance of broiler chickens was carried out for 42 days. 1 - 7 days old chicks were kept in flock cage and given commercial ration, and 8-14 days old chicks and were given feeding adaptation treatment, then $15-42$ days old chicks were given the treatment ration in battery cage. Feeding and drinking water is done by ad libitum.

Table 1. Composition of feed materials and nutritional content of rations

\begin{tabular}{|c|c|c|c|}
\hline \multirow[b]{2}{*}{ Feed Materials } & \multicolumn{3}{|c|}{ Composition } \\
\hline & $\begin{array}{l}\text { Non Micro } \\
\text { Protein } 21 \% \\
\text { (T0) }\end{array}$ & $\begin{array}{c}\text { Non Micro Protein } \\
18 \% \\
\text { (T1 and T3) }\end{array}$ & $\begin{array}{l}\text { Micro Protein 18\% } \\
\quad(\mathrm{T} 2 \text { and } \mathrm{T} 4)\end{array}$ \\
\hline & \multicolumn{3}{|c|}{ 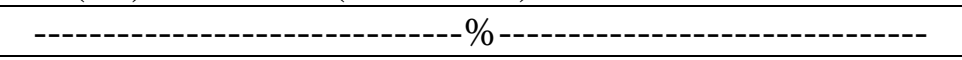 } \\
\hline Milled Corn & 43,20 & 50,80 & 50,80 \\
\hline Bran & 20,00 & 20,00 & 20,00 \\
\hline Soybean meal & 26,40 & 20,70 & - \\
\hline $\begin{array}{l}\text { Soybean meal } \\
\text { microparticles }\end{array}$ & - & - & 20,70 \\
\hline Fish flour & 8,80 & 6,90 & - \\
\hline $\begin{array}{l}\text { Tepung ikan } \\
\text { mikropartikel }\end{array}$ & - & - & 6,90 \\
\hline $\mathrm{CaCO}_{3}$ & 0,60 & 0,60 & - \\
\hline Egg shells microparticle & - & - & 0,60 \\
\hline Premix $^{4}$ & 1,00 & 1,00 & 1,00 \\
\hline Total & 100 & 100 & 100 \\
\hline \multicolumn{4}{|l|}{ Nutrition Content (\%) } \\
\hline $\begin{array}{l}\text { Metabolism Energy } \\
(\mathrm{kkal} / \mathrm{kg})^{1}\end{array}$ & 3021 & 3042,69 & 3042,69 \\
\hline Crude Protein & 21,03 & 18,14 & 18,14 \\
\hline Metionin $^{3}$ & 0,43 & 0,38 & 0,38 \\
\hline $\operatorname{Lisin}^{3}$ & 1,31 & 1,08 & 1,08 \\
\hline $\operatorname{Arginin}^{3}$ & 1,48 & 1,25 & 1,25 \\
\hline Crude Fat & 4,39 & 4,02 & 4,02 \\
\hline Crude Fiber $^{2}$ & 5,78 & 5,32 & 5,32 \\
\hline Calcium $^{2}$ & 1,03 & 0,93 & 0,93 \\
\hline Phospor $^{2}$ & 0,65 & 0,62 & 0,62 \\
\hline \multicolumn{4}{|c|}{$\begin{array}{l}\text { Sources: }{ }^{1} \text { Calculation Result using Balton Formula, } 1982 . \\
{ }^{2} \text { Results of the analysis of feed materials in the laboratory of Agricultural, } \\
\text { Food, and Nutritional Sciences, Faculty of Animal and Agricultural } \\
\text { Sciences, Diponegoro University } \\
{ }^{3} \text { Calculated based on the amino acid content of the constituent feed } \\
\text { ingredients in NRC table, } 1998 \\
{ }^{4} \text { Premix brand Medion contains } \mathrm{Ca}, \mathrm{P}, \mathrm{Mn}, \mathrm{I}, \mathrm{Cu} \text { and } \mathrm{Zn}\end{array}$} \\
\hline
\end{tabular}


The study uses 5 treatments and 4 repeats each of them consists of 8 broiler chickens. The experimental design used is complete random design (RAL). The treatments used include:

T0 : non microparticle feed (protein $21 \%$ ).

$\mathrm{T} 1$ : non microparticle feed (protein $18 \%)+$ Lactobacillus sp $1.2 \mathrm{ml}\left(10^{8} \mathrm{cfu} / \mathrm{ml}\right)$

T2 : non microparticle feed (protein 18\%) + citric acid $1.2 \%$

T3 : microparticle feed (protein $18 \%)+$ Lactobacillus $\mathrm{sp} 1.2 \mathrm{ml}\left(10^{8} \mathrm{cfu} / \mathrm{ml}\right)$

T4 : microparticle feed (protein 18\%) + citric acid 1.2\%

Fat digestibility Parameter was obtained by the total collection method carried out to 40 - 42 days old chickens. The chicken used for the total collection were 20 chickens consisting of 5 treatments and 4 repeat treatments for each 1 chick, then each was given a feed in which the $\mathrm{Fe}_{2} \mathrm{O}_{3}$ indicator was added. The Excreta was accommodated on a plastic coated tray and sprayed using $\mathrm{HCl}$ to bind $\mathrm{N}$. Exkreta was weighed before and after drying. The dried excreta was cleaned of the attached fur, then smoothed and homogenized. The already refined excreta, analyzed fat content. Fat digestibility was measured by analyzing the sample of excreta and then was calculated using the formula according to Kiha et al. (2012):

Fat digestibility $(\%)=\times 100 \%$

Samples of meat and abdominal fats were taken at the slaughter of chicken at the age of 43 days. Meat samples were taken from the chest and the thighs were already separated from the skin. The fat mass of meat is measured by analyzing the fat content of the sample beef and thighs and then calculated using the formula according to Mentari et al. (2014):

Fat meat mass $=\%$ meat fat content $\times$ weight of chest and thigh $(\mathrm{g})$

The amount of abdominal fat is obtained from the fat weighing attached to the abdominal cavity. The percentage of abdominal fat is measured by weighing the abdominal fat and was calculated using the formula according Mangais et al. (2016):

The percentage of abdominal fat $(\%)=$

Weight gain is measured by weighing the weight every week and is calculated using the formula according to Nugraha et al. (2017):

Weight gain $(\mathrm{g})$ = Final body weight $(\mathrm{g})$ - Initial body weight $(\mathrm{g})$

The data obtained further was analyzed using analysis of variance at $5 \%$ of probability and if found a difference it would be continued using Duncan's multiple range test.

\section{Crude Protein Digestibility}

\section{Results and Discussion}

Statistical analysis results presented in Table 2 indicates that the use of protein feed and calcium microparticles with Lactobacillus acidophilus (T3) has significantly lower effect $(\mathrm{P}<0.05)$ on the digestibility of fats and does not differ from the use of nonmicroparticle rations plus Lactobacillus acidophilus (T1) and the use of microparticle rations plus citric acid (T4).

Ration treatment with the feed material of protein source and calcium microparticles plus Lactobacillus acidophilus (T3) shows the same fat digestibility of ration treatment with the feed material of protein source and calcium non microparticles plus Lactobacillus acidophilus (T1) as well as treatment with rations with feed 
ingredients of protein source and calcium microparticles plus citric acid (T4). This suggests that the use of Lactobacillus acidophilus can work well on microparticle and non-microparticle rations. It is suspected because the $\mathrm{T} 1$ and $\mathrm{T} 3$ treatments use Lactobacillus acidophilus so that it can create an acidic atmosphere and increase the amount of lactic acid bacteria (BAL) on the gastrointestinal tract. Increased number of BAL can cause Bile Salt Hydrolase (BSH) enzymes that serve to suppress fat digestibility in broiler chickens can be produced optimally. According to Harumdewi et al. (2018) Lactobacillus Acidophilus is able to produce the enzymes of BSH and form the bile salts of deconjugations that are not easily emulsify fats, so that the fat can be digestible decreases. Treatment with protein rations and calcium microparticles plus citric acid (T4) can provide the same condition of digestive tract as T1 and T3. The administration of citric acid provides an optimal digestive tract atmosphere to increase the amount of lactic acid bacteria. According to Natsir and Sjofjan (2008) Citric acid can maintain the balance of microbes in the gastrointestinal tract. The acidic atmosphere of the gastrointestinal tract can cause lipase enzymes to be unable to work optimally. According to Kirana et al. (2017) Low pH causes lipase enzyme activity does not work optimally so that fat digestibility decreases.

Table 2. Average Fat Digestibility, fat mass in meat, Abdominal fat of Broiler chickens and body weight increase

\begin{tabular}{lccccc}
\hline \multicolumn{1}{c}{ Parameter } & \multicolumn{5}{c}{ Treatment } \\
\hline T0 & T1 & T2 & T3 & T4 \\
\hline Frude Fat Digestibility (\%) & $85.01^{\mathrm{a}}$ & $82.67^{\mathrm{abc}}$ & $83.29^{\mathrm{ab}}$ & $80.04^{\mathrm{c}}$ & $80.92^{\mathrm{bc}}$ \\
\hline Abdominal Fat $(\%)$ & $26.98^{\mathrm{b}}$ & $38.00^{\mathrm{a}}$ & $36.51^{\mathrm{a}}$ & $25.90^{\mathrm{bc}}$ & $20.36^{\mathrm{c}}$ \\
\hline Weight gain(g) & $1.07^{\mathrm{c}}$ & $2.16^{\mathrm{b}}$ & $2.66^{\mathrm{a}}$ & $1.39^{\mathrm{c}}$ & $1.15^{\mathrm{c}}$ \\
\hline
\end{tabular}

Different superscripts in the same column indicate the difference in the effect of the treatment $(\mathrm{P}<0.05)$.

\section{Fat mass of meat}

Statistical analysis results presented in table 2 indicates that the use of protein feed and calcium microparticles with Lactobacillus acidophilus or citric acid have real effects $(\mathrm{P}<0.05)$ on the fat mass of meat. Based on Duncan's further testing, feed treatment of microparticles plus citric acid (T4) shows the fat mass of meat that is no different from the microparticle feed treatment plus the use of non-microparticle rations plus Lactobacillus acidophilus (T3).

Low meat fat masses in T3 and T4 are in line with low fat digestibility as well. T3 and T4 treatments use additional citric acid and Lactobacillus acidophilus thereby resulting in an acidic atmosphere that causes the amount of lactic acid bacteria to increase. An increase in the number of lactic acid bacteria can cause the Bile Salt Hydrolase (BSH) enzyme to be optimally generated. The use of microparticles on rations can also cause nutrients in the rations to be easily absorbed by the intestines and bacteria in the intestines. Bacteria in the intestines are easier to utilize soybean oligosaccharide in microparticle soybean meal making it easier to develop. It is suspected that the utilization of bacteria in the intestines is easier to utilize food fibre or carbohydrates that can not be digested by the body that is the form of oligosaccharides. According to Haryati et al. (2010) The oligosaccharides that can be used as prebiotics in soybean meal are stachiose and raffinose that cannot be solved in the digestive tract 
because there is no $\alpha$-galactosidase enzyme. The use of oligosaccharides in soybean meal by Lactobacillus acidophilus can lead to decreased $\mathrm{pH}$ in the intestines. According to Haryati and Supriyati (2010) Soybean oligosaccharide (SOS) can be utilized by some bacteria in the intestines such as Bifidobacteria and Lactobacillus and produce short chain fatty acids (SCFA) which causes a decrease in $\mathrm{pH}$. SCFA produced primarily propionate can inhibit lipogenesis. According to Abdurrahman and Yanti (2018) Propionate produced by the fermentation of bacteria can inhibit the process of lipogenesis in the liver so that the fat content in the flesh decreases.

The T1 and T2 treatments have a high fat mass of meat compared to T3 and T4. This suggests that non-microparticle feed treatment with low protein and augmented citric acid or Lactobacillus acidophilus has not been effective in suppressing fat mass meat. It is suspected because the T1 and T2 treatment of soybean oligosaccharides (SOS) contained in soybean meal is still in macroparticle form so that it has not been utilized properly by lactic acid bacteria and causes no fermentation happens to the fullest. Minimum SOS fermentation caused the BSH enzyme to not produce optimally, so it can not suppress the fat mass of meat. Based on the research Harumdewi et al. (2018), treatment with feed material of non microparticle protein sources coupled with Lactobacillus acidophilus has not been able to suppress the fat mass of meat such as treatment using microparticle feed Coupled with Lactobacillus acidophilus.

\section{Abdominal Fat Percentage}

Statistical analysis results presented in table 2 indicates that the use of protein feed and calcium microparticles with Lactobacillus acidophilus or citric acid are of real effect $(\mathrm{P}<0.05)$ against abdominal fat. Based on further testing Duncan's feed treatment of microparticles plus citric acid (T4) shows the same fat mass of meat with microparticle feed treatment plus the use of non-microparticle rations plus Lactobacillus acidophilus (T3).

T3 and T4 treatments on the percentage of abdominal fat are no different, it is also in line with the digestibility of fat and fat mass of meat. It is suspected that in both of these treatments occur an increase in the number of acid bacteria that is $34.75 \times 109$ CFU/g $34.77 \times 109 \mathrm{CFU} / \mathrm{G}$. An increase in the amount of lactic acid bacteria in the gastrointestinal tract causes BSH enzyme to be produced optimally so that it inhibits fat digestibility. The addition of citric acid leads to increased production of lactic acid bacteria (BAL) so that it will inhibit energy formation. According to Sibarani et al. (2014) The addition of acid will inhibit the formation of energy is glycolysis so that the production of triglycerides and acetyl CoA used for the formation of lipid body and abdominal fat decreases. The use of protein and calcium microparticles is easier to utilise compared to the use of macroparticle proteins and calcium. The high content of the digestible or absorbed $\mathrm{Ca}$ causes the process to occur. The process of degrading will lower the deposition of fat in the body because fat will be wasted. According to Fuhrmann and Kamphues (2016) high calcium levels will cause the process of malignancies on the small intestine increases and the absorption of fat will be obstructed and wasted through excreta.

The high abdominal fat that occurs in the T1 and T2 treatment is thought to be due to an accumulation of excess feed consumption. This is caused by consumption is not accompanied by high protein, when the protein in the high ration then the energy consumed is used for the formation of meat or body tissues. According to Silondae and 
Polakitan (2018) The balance of proteins and energy in rations should be adjusted because the protein consumed content is used for growth while the energy content is used to support the activities and productivity of chickens. According to Hidayat (2015) Excess energy consumption is known to affect the amount of abdominal fat deposits in the body of broiler chickens.

\section{Weight Gain}

Statistical analysis results presented in table 2 indicates that the use of protein feed and calcium microparticles with Lactobacillus acidophilus or citric acid are have real effect $(\mathrm{P}<0.05)$ on weight gain. Based on the further test Duncan's treatment of T3 (The feed microparticle protein $18 \%$ + Lactobacillus acidophilus) showed the highest increase in body weight compared to other treaments.

The T3 and T0 treatments Show equal Weight Gain which is thought to be because T3 treatment uses microparticle feed added to Lactobacillus acidophilus. The Weight Gain is affected by protein deposition which is heavily affected by protein digestibility. Protein digestibility in the treatment of T0 and T3 are $82.11 \%$ and $80.39 \%$. Good protein digestibility indicates that the amino acids are sufficient for increased weight gain. According to Suparti et al (2018) The availability of good amino acids will increase the weight gain and chicken weight. The addition of citric acid combined with protein and calcium microparticles can sustain the weight gain because it can help the absorption of calcium and the binding of Ca-citrate so that calcium in blood plasma increases and protein absorption is increased as well. According to Zulfa et al. (2018) The use of organic calcium microparticles combined with citric acid helps the absorption of calcium and is formed Ca-citrate which can increase calcium in blood plasms so that protein absorption increases.

\section{Conclusion}

Based on the results of the study can be concluded that feeding microparticles of proteins and calcium with Lactobacillus acidophilus $1.2 \mathrm{ml}$ can decrease fat digestibility and increase weight gain but does not increase in the fat mass of meat and percentage of abdominal fat.

\section{References}

Abdurrahman, Z. H. dan Y. Yanti. 2018. Gambaran umum pengaruh prebiotik pada kualitas daging ayam. J. Ternak Tropika. 19 (2): 95-104.

Addo, A., A. B. Plange dan J. O. Akowuah. 2012. Particle size evaluation of feed ingredient produced in the Kumasi Metropolis, Ghana. J. Of Agricultural and Biological Science. 7 (3): 177-181.

Cholis, M. A., N. Suthama dan B. Sukamto. 2018. Feeding microparticle protein diet combined with Lactobacllus sp. on existence of intestinal bacteria and growth of broiler chickens. J. Indon. Trop. Anim. Agric. 4 (3): 265-271.

Direktorat Jenderal Peternakan dan Kesehatan Hewan. 2018. Statistik Peternakan dan Kesehatan Hewan. Kementrian Pertanian RI. 
Fadhilah, A. N., Hafsan dan F. Nur. 2015. Penurunan kadar koleterol oleh bakteri asam laktat asal dangke secara in vitro. Prosiding Seminar Nasional Mikrobiologi Kesehatan dan Lingkungan. Makassar, 29 Januari 2015.

Fajrina, I. T., S. Sumarsih dan H. I. Wahyuni. 2014. Pengaruh pemberian limbah pabrik pakan (pakan ceceran) yang difermentasi dengan starter fungsional terhadap profil kolesterol pada ayam broiler. J. Anim. Agric. 3 (3): 463-468.

Fuhrmann, R. dan J. Kamphues. 2016. Effects of fat content and source as well as of calcium and potassium content in the diet on fat excretion and saponification, litter quality and foot pad health in broilers. Europ. Poult. Sci. 80 (1): 1-12.

Harumdewi, E., N. Suthama dan I. Mangisah. 2018. Pengaruh pemberian pakan protein mikropartikel dan probiotik terhadap kecernaan lemak dan perlemakan daging pada ayam broiler. J. Sain Peternakan Indonesia. 13 (3): 258-264.

Haryati, T., K. Suprijati dan I. W. R. Susana. 2010. Senyawa oligosakarida dari bungkil kedelai dan ubi jalar sebagai prebiotik untuk ternak. Prosiding Seminar Nasional Teknologi Peternakan dan Veteriner. Bogor, 3-4 Agustus 2010. Balai Penelitian Ternak. 511-518.

Haryati, T. dan Supriyati. 2010. Pemanfaatan senyawa oligosakarida dari bungkil kedelai dan ubi jalar pada ransum ayam pedaging. J. Ilmu Ternak Veteriner. 15 (4): 253-260.

Hidayat, C. 2015. Penurunan deposit lemak abdominal pada ayam pedaging melalui manajemen pakan. Wartazoa. 25 (3): 125-134.

Kiha, A. F., W. Murningsih dan Tristiarti. 2012. Pengaruh pemeraman ransum dengan sari daun pepaya terhadap kecernaan lemak dan energi metabolis ayam broiler. J. Anim. Agric. 1 (1): 265-276.

Kirana, N. G. P. S., I. G. N. G. Bidura dan E. Puspani. 2017. Pengaruh penggunaan ampas tahu terfermentasi Saccharomyces spp dalam ransum terhadap distribusi lemak dan kolesterol darah broiler. J. Peternakan Tropika. 5 (1): 105-119.

Mangais, G., M. Najoan, B. Bagau dan C. A. Rahasia. 2016. Persentase karkas dan lemak abdomen broiler yang menggunakan daun murbei (Morus alba) segar sebagai pengganti sebagian ransum basal. J. Zootek. 36 (1): 77-85.

Mentari, A. S., L. D. Mahfudz dan N. Suthama. 2014. Massa protein dan lemak daging pada ayam broiler yang diberi tepung temukunci (Boesenbergia pandurata ROXB.) dalam ransum. J. Anim. Agric. 3 (2): 211-220.

Natsir, M. H. dan O. Sjofjan. 2008. Pengaruh penggunaan kombinasi asam sitrat dan asam laktat cair dan terenkapsulasi sebagai adtif pakan terhadap penampilan 
produksi ayam pedaging. Prosiding Seminar Nasional Teknologi Peternakan dan Veteriner. Bogor, 11 - 12 November 2018. Balai Besar Penelitian Veteriner. 636640.

Nugraha, Y. A., K. Nissa, N. Nurbaeti, F. M. Amrullah, dan D. W. Harjanti. 2017. Pertambahan bobot badan dan feed conversion rate ayam broiler yang dipelihara menggunakan desinfektan herbal. J. Ilmu-Ilmu Peternakan. 27 (2): 19-24.

Sibarani, J., V. D. Yunianto dan L. D. Mahfudz. 2014. Persentase karkas dan non karkas serta lemak abdominal ayam broiler yang diberi acidifier asam sitrat dalam pakan double step down. J. Anim. Agric. 3 (2): 273-280.

Silondae, H. dan D. Polakitan. 2018. Pengaruh imbangan energi dan protein serta kepadatan kandang terhadap penampilan ayam pedaging. J. Peternakan Indonesia. 20 (3): $175-180$.

Suparti, I. Mangisah dan B. Sukamto. 2018. Penggunaan probiotik Lactobacillus acidophilus dan mikropartikel cangkang telur untuk menghasilkan daging ayam yang rendah lemak. Buletin Sintesis. 22 (2): 9-12.

Yendy, S. A., I. Mangisah dan B. Sukamto. 2014. Pengaruh penambahan asam sitrat dalam ransum sebagai acidifier terhadap retensi kalsium dan fosfor itik jantan lokal. J. Anim. Agric. 3 (1): 70-78.

Zulfa, O., F. Wahyono dan N. Suthama. 2018. Penggunaan kalsium organik mikropartikel dengan tambahan asam sitrat terhadap bobot organ limfoid ayam broiler. Prosiding Seminar Nasional Pertanian Peternakan Terpadu 2. Purworejo, 17 Maret 2018. Universitas Muhammadiyah Purworejo, Purworejo. 199-208. 